\section{Pd-Catalyzed Asymmetric Cross-Coupling of Allyl Carbonates and Allyl Boronates}

Metal-Catalyzed Asymmetric Synthesis and Stereoselective

Reactions

\section{Key words}

palladium-catalyzed cross-coupling

allyl carbonates<smiles>C=CC(O)O</smiles>

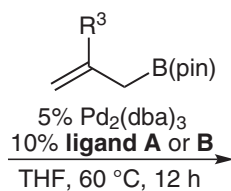<smiles>[B]C(C)CC([18OH])C=C</smiles>

$\mathrm{R}^{1}=\mathrm{Ar}$ or Alk $\mathrm{R}^{2}=\mathrm{CO}_{2} t-\mathrm{Bu}$ or $\mathrm{CO}_{2} \mathrm{Me}$<smiles>COc1cccc(P(N)(=O)c2ccccc2)c1-c1ccccc1</smiles><smiles>CCC(C)[P+](C)c1nc2ccccc2nc1P(C)C</smiles>
ligand $A$ chiral phosphine

ligands

deuterium labeling

Selected examples:<smiles>C=CCC(C=C)c1ccccc1</smiles>

$72 \%$ yield $91 \%$ ee regioselectivity $>20: 1$<smiles>C=CCC(C=C)c1ccc2c(c1)OCO2</smiles>

$83 \%$ yield regioselectivity $>20: 1$ regioselectivity $>20: 1$ $91 \%$ ee<smiles>C=CCC(C=C)c1cccnc1</smiles>

$90 \%$ ee<smiles>C=CCC(C=C)CCOCC</smiles>

$75 \%$ yield regioselectivity $>20: 1 \quad$ regios $80 \%$ yield $85 \%$ yield $20: 1 \quad$ regioselectivity $=11: 1$
Plausible mechanistic pathways:

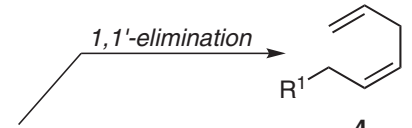

B/Pd transmetalation

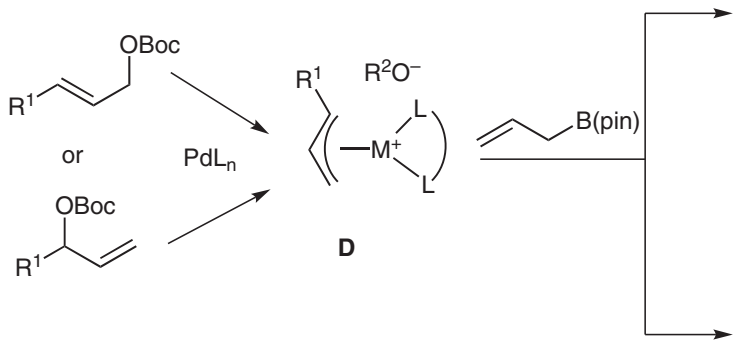

minor regioisomer
Significance: The authors describe here a highyielding, highly regio- and enantioselective crosscoupling of allyl carbonates and allyl boronates. Remarkably, nearly identical results are obtained for regioisomers $\mathbf{1}$ and $\mathbf{2}$. Importantly, aromatic and aliphatic allyl carbonates are tolerated under the reaction conditions. Allyl-allyl coupling in high regio- and stereoselectivity is a long-standing challenge in organic synthesis and this method provides an excellent solution.

SYNFACTS Contributors: Hisashi Yamamoto, Patrick Brady Synfacts 2010, 11, 1255-1255 Published online: 21.10.2010 Dol: 10.1055/s-0030-1258743; Reg-No.: H12010SF
Comment: High regioselectivity for the branched product $\mathbf{3}$ rather than the linear product $\mathbf{4}$ is obtained by choosing bidentate ligands with small bite angles. Mechanistic studies including deuterium labeling and stereochemical analysis support a B-Pd transmetalation pathway to generate intermediate $\mathbf{C}$, followed by 3,3'-elimination, rather than a backside outer-sphere attack (E). 